\title{
Effect of Meat and Bone Meal Substitutes in Feed Mixes on Quality Indicators of Turkey Breast Meat
}

\author{
M. SLEPIČKOVÁ ${ }^{1}$, L. VORLOVÁ \\ ${ }^{1}$ Regional Veterinary Administration for Karlovy Vary Region \\ ${ }^{2}$ Faculty of Veterinary Hygiene and Ecology, University of Veterinary and Pharmaceutical Sciences Brno
}

Received August 13, 2007

Accepted February 14, 2008

\begin{abstract}
Slepičková M., L. Vorlová: Effect of Meat and Bone Meal Substitutes in Feed Mixes on Quality Indicators of Turkey Breast Meat. Acta Vet. Brno 2008, 77: 297-304.

We analyzed turkey breast meat composition in dependence on the presence of proteins of meat and bone meal origin in the feed mixes used.

Farmers involved in the research with comparable zoohygienic and technological conditions of poultry management were divided into two groups. The principal difference between the groups was in the feed mixes they used. Poultry in Group 1 was fed feed mixes containing a total of 7.2 $9.5 \%$ of meat and bone meal, fish meal and poultry meal and of $3.4-36.8 \%$ of soybean according to the age category as the main source of protein. In Group 2 the nutritious portion of meat and bone meal-based protein was substituted with soybean meal. Feed mixes fed to turkeys in Group 2 contained 9.35 - 35.25\% soybean meal depending on the age group.

Between 2002 and 2003, turkey meat samples were collected at a turkey slaughterhouse. The samples were cooled to $+4{ }^{\circ} \mathrm{C}$ and examined for meat binding characteristics, water content, and total fat. The remaining parts of samples were frozen and pooled. Then they were tested for their content of total protein, net muscle protein, collagen and 9 fatty acids (myristic, palmitic, stearic, palmitoleic, oleic, eicosanic, erucic, linoleic and linolenic).

Evaluation of the results showed that the absence of meat and bone meal in feed mixes had no effect on the indicators important for technological properties of male turkey breast muscle (meat binding characteristics, water content, content of total protein, net muscle protein and collagen).

The results of the study, however, also demonstrated a decrease in total lipids $(p<0.05)$ and a change in the composition of fatty acids when meat and bone meal was replaced with soybean meal (Group 2). Also increased were the levels of palmitic, stearic and eicosanic fatty acids. The difference between eicosanic fatty acid levels was significant $(p<0.05)$. In the same group of birds, the level of oleic acid also decreased $(p<0.01)$.

The change in total lipids and in the composition of fatty acids of male turkey breast muscle might be important with regards to human health (particularly cardiovascular and cancer diseases).
\end{abstract}

Turkey, breast meat, fatty acids, meat and bone meal

Meat and bone meal (MBM) was successfully introduced to poultry diets dozens of years ago. In fact, poultry industry has been the biggest single user of MBM of all meat production sectors. Although the successful use of MBM depended on economic benefits it offered in the availability of nutrients, such as essential fatty acids, calcium, phosphorus and energy, the historical tradition of MBM use derived from its protein content (Kirstein 2005).

In recent decades, people have become more aware of the risks posed by various transmission spongiform encephalopathies, and particularly of bovine spongiform encephalopathy (BSE). Because BSE is classified as a food-borne disease, the European Parliament took an essential precaution in its resolution of November 16, 2000 on BSE and food safety, calling on a ban of animal proteins for feeding farm animals (Regulation (EC) of the European Parliament and the Council of 2002).

Poultry farmers adjusted their feed mixes, although it is obvious that of the total

Address for correspondence:

Prof. MVDr. Lenka Vorlová, Ph.D.

Department of Milk Hygiene and Technology

Faculty of Veterinary Hygiene and Ecology

University of Veterinary and Pharmaceutical Sciences Brno

Palackého 1-3, 61200 Brno, Czech Republic 
nitrogenous substances in poultry diets, $25 \%$ should be of animal origin (Labuda et al. 1975).

Turkey is a gallinaceous bird which, when raised in open conditions, will on its own seek out some food of animal origin. Replacing MBM with plant-based proteins has given rise to the question of whether the absence of animal proteins in feedstuffs might affect negatively the quality of meat produced from poultry raised on such a diet.

The chemical composition of meat is dependent on a number of factors, including the breed and sex of farm animals, their age at slaughter, and on seasonal effects, but first and foremost it depends on the type of feeding and feedstuff composition (Labuda et al. 1973; Rule et al. 2002).

It has been demonstrated that there is a close connection between health and diet (Ferreira et al. 2000). Health risks associated with the consumption of meat are frequently debated by specialists from various fields. The risk of cardiovascular and oncological diseases and of diabetes is particularly important in this respect (Okuyama et al. 1997). Increased dietary uptake of cholesterol and saturated fatty acids seems to be the main risk factor for the coronary heart disease (Steinhauser et al. 1995; Lorgeril et al. 1996; Iso et al. 2001).

Poultry meat, and gallinaceous poultry meat in particular, is characterized by higher protein and lower fat contents than those found in the meat of other slaughter animals, and its lower energy value makes it particularly suitable with regard to the nutritional requirements in support of health. Poultry fat is different from the fat of other slaughter animals by more favourable proportions of fatty acids, particularly unsaturated fatty acids. Its biological value is also very high due to its high concentrations of essential fatty acids, particularly of linoleic acid (Izák et al. 1978).

Considering the abovementioned facts, a considerable amount of research has been done on the composition and quality of breast meat in turkeys.

The aim of the study reported here was to compare the chemical composition of breast meat of carcasses of turkeys fed feed mixes differing in the character of their protein component.

\section{Materials and Methods}

Samples of breast meat from turkey carcasses slaughtered at ADEX a.s., a turkey slaughter house based in Lom u Tachova, Czech Republic, were collected in 2002 and 2003. Turkey raisers had been selected in advance on the basis of identical zootechnological conditions, type of management and feeding.

Male turkeys (Big 6, Hybrid Large White) were fattened separately in two stages. The first stage was up to the age of 6 or 8 weeks. The turkey chicks were then taken to a turkey fattening operation for the second stage. During this period, the turkeys were kept on bedding, drinking water was provided by means of suspended water cups, and food was delivered by means of screw feeders that ran along the entire length of the feeding hall. The lightdark cycle in the halls was adjusted by artificial lighting. In all cases, turkeys were fed commercial feed mixes. Feed mixes from the so-called starter (K1) to finisher (K6) mixes with gradually decreasing concentrations of nitrogenous substances (Tables 3 and 4) were used for the feeding organised in six stages.

Fattened males were slaughtered at 20 to 21 weeks of age at the live weight of $17-20 \mathrm{~kg}$. Group 1 consisted of samples $(n=30)$ collected from turkeys whose diet included protein of animal origin, i.e., their feed mixes contained meat and bone meal, fish meal and poultry meal. Protein of plant origin was represented by extracted soybean meal at amounts depending on the age category $(3.4-36.8 \%)$. In Group $2(n=25)$, the nutritious portion of meat and bone meal-based protein was substituted with soybean meal. Feed mixes fed to turkeys in Group 2 contained $9.35-35.25 \%$ soybean meal depending on age group.

\section{Collection of samples}

Turkey carcasses were chilled to $+4{ }^{\circ} \mathrm{C}$ and taken to the laboratory of the ADEX Company where samples of the breast muscle ( $\mathrm{m}$. pectoralis profundus) weighing about $500 \mathrm{~g}$ were collected.

All the collected samples were divided into two parts. The first part of collected samples was placed in a refrigerator at $+4{ }^{\circ} \mathrm{C}$ and was used for the determination of physical and chemical variables (water content in meat, fat content, binding characteristics). These tests were performed on the same day in the ADEX company laboratory.

The second part of samples was used for the determination of the meat nutritious indicators (total protein, net 
muscle protein, collagen, fatty acids content). The samples were packed in microtene bags, frozen to $-18{ }^{\circ} \mathrm{C}$ and kept at that temperature until analyzed.

Methods

The water content in meat was determined gravimetrically according to the Czech standard ČSN 576021 (1999) by drying specimens in sand to a constant weight at $103 \pm 2{ }^{\circ} \mathrm{C}$.

The fat content was determined quantitatively by extraction with solvents on the Soxtec semi-automatic unit (Tecator, Sweden) using the procedure recommended by the manufacturer (AN 67/83).

Binding properties of the meat were determined from the loss of fluid from the homogenate after heating. A total of $80 \mathrm{~g}$ meat, $120 \mathrm{~g}$ water and $5 \mathrm{~g} \mathrm{NaCl}$ were homogenized in a mixer and poured in $50-70 \mathrm{~g}$ batches to saturation test tubes. The test tubes covered with an aluminium sheet were placed to a water bath heated to $75^{\circ} \mathrm{C}$ for $30 \mathrm{~min}$. After that period, the fluid released was removed, the test tubes were allowed to cool and drain off, and weighed (Brendl 1970).

The total protein content was determined on a semi-automatic Kjeltec System analyzer (Tecator, Sweden) using the procedure recommended by the manufacturer (AN 86/87).

The net protein content had to be ascertained before the net muscle protein content was determined. The net muscle protein content was determined in a similar way as the net protein content by precipitation with a hot tannin solution. The net muscle protein content was determined by deducting the collagen content from the net protein content.

The collagen content was calculated from the content of the amino-acid hydroxyproline, which was quantified by photometric absorbance measurements at $550 \mathrm{~nm}$ using a spectrophotometer (Carl Weiss Jena, Germany).

Fatty acids were determined by the high resolution capillary gas chromatography (HRGC) and the flame ionizing detector (FID) on the gas chromatographer HP 5890 Series II (Agilent Technologies, USA) and silicone capillary columns with sunflower oil and pork lard used as reference materials. In the study, methyl esters of nine fatty acids (myristic, palmitic, stearic, palmitoleic, oleic, eicosanic, erucic, linoleic and linolenic acids) were determined. Individual fatty acid methyl esters were identified according to retention times on the basis of an analysis of standard mixtures. For quantitative evaluations, the external standard (absolute calibration) method was used at concentration levels of 1,10 and $100 \mathrm{ng} / \mu 1$. Results of determinations were calculated automatically using the HP Vectra computer and the Chemstation A.03.34 software (Agilent Technologies, USA). The results of determinations are given in percentages of the total fatty acid content.

For the statistical evaluation of differences in values of the variables investigated between Groups 1 and 2 , Student's $t$-test was used (Novovičová 1999). All results were processed using the Excel Office 2003 software.

\section{Results and Discussion}

Any comparison between values obtained in the indicators investigated in our study and available literature data is very difficult because few data have been published on physical and chemical variables of turkey muscle in dependence on the use of meat and bone meal in turkey diets.

Water contents in Group 1 and Group 2 were $73.69 \pm 1.27 \%$ and $73.30 \pm 1.08 \%$, respectively.

Meat binding in Group 1 and Group 2 was $66.71 \pm 12.42 \%$ and $62.31 \pm 13.24 \%$, respectively.

The total protein content and the net muscle protein content in the two groups of samples were almost identical $(25.03 \pm 0.68$ and $22.91 \pm 0.89 \%$ in Group 1 and $25.11 \pm 0.73$ and $22.83 \pm 0.64 \%$ in Group 2). Contents of the most important stromatic protein collagen in Group 1 and Group 2 were $0.41 \pm 0.18 \%$ and $0.32 \pm 0.12 \%$, respectively.

A comparison of the above values shows that the differences between the two groups in the variables investigated were not significant $(p>0.05)$.

A different situation was found in the total lipid content and in the composition of fatty acids in turkey breast meat. A comparison of mean fat contents in samples from Group $1(2.08 \pm 0.79 \%)$ and Group $2(1.55 \pm 0.86 \%)$ showed a significant difference between them $(p<0.05)$. Results similar to those obtained in our group of animals fed mixes without meat and bone meal were reported by Blažková (2001) and Decker and Cantor (1992), who mentioned the mean fat content in turkey breast meat of $14.7 \pm 2.7 \mathrm{~g} / \mathrm{kg}$ and $16.0 \mathrm{~g} / \mathrm{kg}$, respectively. Significantly lower total lipid content in turkey breast meat was reported in the study by Komprda (2003). In animals fed feed mixes containing sunflower seeds, linseed seeds or fish oil, total lipid contents ranged from 0.73 to $0.78 \%$.

With respect to the fatty acid content in individual groups of turkey breast meat samples 
Table 1. Mean content of fatty acids in individual groups of samples [\%]

\begin{tabular}{|l|r|r|r|r|}
\hline \multirow{2}{*}{ Fatty acid } & \multicolumn{4}{|c|}{ Group } \\
\cline { 2 - 5 } & \multicolumn{2}{|c|}{$1(\mathrm{n}=30)$} & \multicolumn{2}{c|}{$2(\mathrm{n}=25)$} \\
\cline { 2 - 5 } & Max. & Min. & Max. & Min. \\
\hline Myristic & 1.36 & 0.75 & 1.33 & 0.84 \\
\hline Palmitic & 31.37 & 22.14 & 37.83 & 22.32 \\
\hline Stearic & 11.09 & 6.95 & 11.08 & 6.97 \\
\hline Palmitoleic & 8.45 & 4.25 & 7.04 & 4.37 \\
\hline Oleic & 43.80 & 34.67 & 40.34 & 34.02 \\
\hline Eicosanic & 0.98 & 0.46 & 1.12 & 0.58 \\
\hline Erucic & $<0.05$ & $<0.05$ & $<0.05$ & $<0.05$ \\
\hline Linoleic & 23.47 & 6.43 & 24.68 & 3.36 \\
\hline Linolenic & 2.39 & 0.16 & 1.17 & 0.16 \\
\hline
\end{tabular}

Table 2. Comparison between fatty acid contents found in our study and fatty acid contents in poultry breast meat reported by other authors [\%]

\begin{tabular}{|l|c|c|c|c|}
\hline Fatty acid & Group & $\begin{array}{c}\text { Group } \\
1\end{array}$ & $\begin{array}{c}\text { Komprda } \\
(2001)\end{array}$ & $\begin{array}{c}\text { Nam } \\
(1997)\end{array}$ \\
\hline Myristic & 1.03 & 1.04 & 0.99 & 1.15 \\
\hline Palmitic & 26.33 & 28.87 & 24.32 & 21.39 \\
\hline Stearic & 8.44 & 9.08 & 9.95 & 9.56 \\
\hline Palmitoleic & 6.10 & 5.72 & 6.14 & 2.03 \\
\hline Oleic & 38.92 & 36.93 & 28.48 & 24.48 \\
\hline Eicosanic & 0.70 & 0.82 & 0.30 & - \\
\hline Linoleic & 16.30 & 15.67 & 21.54 & 15.96 \\
\hline Linolenic & 1.25 & 1.38 & 0.11 & 3.49 \\
\hline
\end{tabular}

(Table 1 and Fig. 1), we may conclude that contents of saturated fatty acids, i.e. of myristic acid (C14:0), palmitic acid (C16 : 0), stearic acid (C18:0) and monounsaturated palmitoleic acid $(\mathrm{C} 16: 1)$ that we obtained are comparable with those reported in the study by Komprda et al. (2001, 2005).

The issue of fatty acid content induced by dietary changes and modified feed rations has been studied by a number of authors. For instance, a significant decrease $(p<0.05)$ was observed in contents of palmitic, palmitoleic and oleic acids and a significant increase in contents of linoleic and $\alpha$-linolenic acids $(p<0.05)$ was observed in chickens fed feed rations containing seeds of Salvia hispanica L. The lower content of saturated fatty acids resulted in a decrease in the saturated-to-polyunsaturated fatty acids ratio (Ayerza et al. 2002). In male turkeys fed meat and bone meal compared with those fed soybean meal, the content of palmitic acid was lower, contrary to the palmitoleic acid content which was higher; however, these differences were not significant. Considerable differences in the composition of fatty acids in dependence on the composition of feed rations have also been reported by Komprda et al. (2003). He found that feeding a fish oil-containing diet resulted in a higher $(p<0.05)$ content of oleic acid and total mono-unsaturated fatty acids than if a diet containing linseed and sunflower seeds was used. In the same group, he found lower contents of linoleic acid and of total poly-unsaturated fatty acids. The highest content of linoleic acid was found in a group of male turkeys fed sunflower oil.

In the reported research the content of oleic acid was significantly higher $(p<0.01)$ in the group of male turkeys fed meat and bone meal. The proportion of monounsaturated fatty acids (MUFA) reveals similar results. The total amount of polyunsaturated fatty acids (PUFA) showed hardly any differences between the groups $(p>0.05)$.

Feeding meat and bone meal to cattle resulted in a decrease in total lipids and an increase in cholesterol levels. The highest content was found in monounsaturated fatty acids, of which oleic acid ranked highest. Of saturated fatty acids, it was mainly palmitic acid (Da Silva et al. 2002).

Compared with studies involving cattle fed meat and bone meal, in our study in turkeys fed feed mixes supplemented with meat and bone meal, a higher content of total lipids in breast meat $(p<0.05)$ and lower percentage ratios of palmitic, stearic and eicosanic acids of the total content of fatty acids were found. In the case of eicosanic acid, the difference was significant $(p<0.05)$. On the other hand, a highly significant increase in the oleic acid content in this group was demonstrated $(p<0.01)$. In our study, the content 
Table 3. Main components of feed mixes fed to Group 1 [\%]

\begin{tabular}{|l|c|r|r|r|r|c|}
\hline \multirow{2}{*}{ Components } & \multicolumn{7}{|c|}{ Feed mixes } \\
\cline { 2 - 7 } & \multicolumn{1}{|c|}{ K1 } & K2 & \multicolumn{1}{c|}{ K3 } & K4 & \multicolumn{1}{c|}{ K5 } & K6 \\
\hline Wheat & 35.00 & 43.00 & 49.00 & 56.40 & 67.00 & 75.50 \\
\hline Maize & 12.00 & 10.00 & 8.00 & 6.00 & 5.00 & 3.00 \\
\hline Extracted soybean meal & 31.80 & 27.00 & 22.00 & 17.00 & 7.00 & 3.40 \\
\hline Presco soybean & 5.00 & 3.00 & 3.00 & 3.00 & 2.00 & 0.00 \\
\hline Rapeseed expellent & 1.00 & 1.00 & 2.00 & 3.00 & 3.00 & 3.00 \\
\hline Meat and bone meals & 3.00 & 4.00 & 4.00 & 5.20 & 7.50 & 9.00 \\
\hline Fish meal & 3.50 & 3.00 & 2.00 & 1.00 & 0.00 & 0.00 \\
\hline Poultry meal & 2.00 & 2.00 & 2.00 & 1.00 & 2.00 & 0.00 \\
\hline Vitex fermentum & 1.00 & 1.00 & 1.00 & 1.00 & 0.00 & 0.00 \\
\hline Animal fat & 1.00 & 1.70 & 2.00 & 2.20 & 3.00 & 4.00 \\
\hline Soybean oil & 0.70 & 1.00 & 1.00 & 1.00 & 1.00 & 0.80 \\
\hline Essential amino acids & & & & & & \\
\hline Lysine & 1.80 & 1.61 & 1.39 & 1.23 & 1.00 & 0.91 \\
\hline Methionine & 0.69 & 0.62 & 0.51 & 0.52 & 0.46 & 0.34 \\
\hline Total sulphur amino acids & 1.13 & 1.03 & 0.90 & 0.89 & 0.80 & 0.65 \\
\hline Threonine & 1.05 & 0.96 & 0.92 & 0.77 & 0.63 & 0.53 \\
\hline Tryptophan & 0.34 & 0.31 & 0.28 & 0.25 & 0.20 & 0.17 \\
\hline Nutritional and energy values & & & & & & \\
\hline $\begin{array}{l}\text { Metabolisable energy } \\
\text { [MJ/kg] }\end{array}$ & 11.73 & 12.13 & 12.21 & 12.45 & 13.04 & 13.29 \\
\hline Total nitrogenous substances & 27.86 & 25.73 & 23.44 & 21.44 & 18.21 & 16.00 \\
\hline Total lipids & 5.16 & 5.91 & 6.31 & 6.70 & 7.66 & 8.03 \\
\hline Fatty acids & & & & & & \\
\hline Linoleic acid & 1.84 & 1.87 & 1.91 & 1.97 & 1.97 & 1.76 \\
\hline
\end{tabular}

Table 4. Main components of feed mixes fed to Group 2 [\%]

\begin{tabular}{|l|r|r|r|r|r|r|}
\hline \multirow{2}{*}{ Components } & \multicolumn{7}{|c|}{ Feed mixes } \\
\cline { 2 - 7 } & \multicolumn{1}{|c|}{ K1 } & \multicolumn{1}{c|}{ K2 } & \multicolumn{1}{c|}{ K3 } & \multicolumn{1}{c|}{ K4 } & \multicolumn{1}{c|}{ 5} & K6 \\
\hline Wheat & 22.00 & 33.00 & 49.12 & 61.11 & 66.25 & 67.14 \\
\hline Maize & 20.00 & 15.00 & 8.00 & 0.00 & 0.00 & 0.00 \\
\hline Extracted soybean meal & 35.25 & 31.10 & 23.11 & 19.99 & 13.39 & 9.35 \\
\hline Fish meal & 4.00 & 2.50 & 2.00 & 1.00 & 1.00 & 0.00 \\
\hline Animal fat & 0.00 & 3.25 & 3.80 & 5.40 & 5.70 & 5.85 \\
\hline Soybean oil & 2.20 & 0.00 & 0.00 & 0.00 & 0.00 & 0.00 \\
\hline Essential amino acids & & & & & & \\
\hline Lysine & 1.73 & 1.56 & 1.35 & 1.10 & 0.97 & 0.87 \\
\hline Methionine & 0.71 & 0.65 & 0.59 & 0.50 & 0.50 & 0.43 \\
\hline Total sulphur amino acids & 1.13 & 1.05 & 0.95 & 0.85 & 0.82 & 0.74 \\
\hline Threonine & 1.08 & 0.97 & 0.88 & 0.69 & 0.61 & 0.57 \\
\hline Tryptophan & 0.35 & 0.31 & 0.27 & 0.25 & 0.22 & 0.21 \\
\hline Nutritional and energy values & & & & & & \\
\hline $\begin{array}{l}\text { Metabolisable energy } \\
\text { [MJ/kg] }\end{array}$ & 11.60 & 11.82 & 12.10 & 12.40 & 12.70 & 12.91 \\
\hline Total protein & 27.55 & 25.01 & 22.00 & 20.00 & 18.02 & 17.00 \\
\hline Total lipids & 6.50 & 6.92 & 7.05 & 8.05 & 8.58 & 9.38 \\
\hline Fatty acids & & & & & & \\
\hline Linoleic acid & 2.82 & 1.88 & 1.82 & 1.84 & 1.97 & 2.34 \\
\hline
\end{tabular}




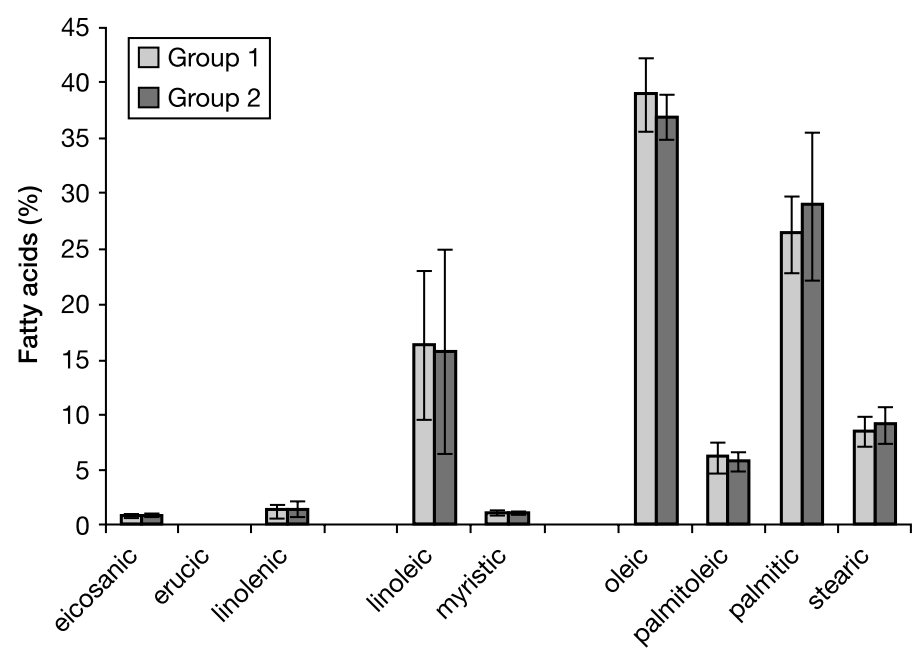

Fig. 1. Concentration of fatty acids in individual groups of samples

of monounsaturated acids was the highest in both groups of experimental animals, i.e. a group fed a feed mix supplemented with meat and bone meal and a group fed a feed mix containing no meat and bone meal $(45.72 \%$ and $43.47 \%$, respectively). As in cattle, higher oleic acid content was found here $(38.92 \%$ and $36.93 \%$, respectively). In this group of fatty acids, a significant difference $(p<0.05)$ was also found in the eicosanic acid content $(0.70 \%$ and $0.82 \%$, respectively). Palmitic acid had the highest content from among saturated fatty acids (26.33\% and $28.87 \%$, respectively).

In terms of variables important for technological properties of male turkey breast muscle (meat binding characteristics, water content, content of total protein, net muscle protein and collagen) due to a change in feedstuff composition, i.e., replacement of meat and bone meal (traditionally used in the Czech Republic as an ingredient of poultry feedstuffs) by soybean meal, no significant effects were observed $(p>0.05)$.

However, an indicator frequently discussed from the dietetic and human health point of view, i.e., the lipid content, decreased significantly in group $2(p<0.05)$ due to the replacement of meat and bone meal by soybean meal. Reduction in the total lipid content, on one hand, is accompanied by an increase in the saturated fatty acids (SFA) content, on the other hand, with a decrease in monounsaturated fatty acids content. The polyunsaturated fatty acids content is nearly identical in both groups. Reduction in the total amount of monounsaturated fatty acids in group 2 is substantially $(p<0.01)$ influenced by a decrease in the oleic acid content.

The change in total lipids and in the composition of fatty acids (increase in the SFA content and reduction in the oleic acid content) of male turkey breast muscle may be important from the human health point of view, particularly with regard to cardiovascular and cancer diseases.

\section{Vliv nahrazení masokostní moučky v krmných směsích na jakostní indikátory krůtí prsní svaloviny}

Sledovali jsme složení krůtí prsní svaloviny v závislosti na přítomnosti, resp. absenci bílkovin masokostní moučky v krmných směsích u krocanů.

Byly vytvořeny dvě skupiny chovatelů se srovnatelnými zoohygienickými a techno- 
logickými podmínkami výkrmu drůbeže. Hlavní rozdíl byl v používaných krmných směsích, kdy ve skupině 1 byla drůbež krmena směsmi obsahujícími jako zdroj bílkovin masokostní, rybí a drůbeží moučku v celkovém množství 7,20 - 9,50 \% a soju v množství $3,4-36,8 \%$ v závislosti na věkové kategorii krmených ptáků. Ve skupině 2 byl výživový podíl bílkovin masokostní moučky nahrazen moučkou sojovou. Krmné směsi, použité k výživě krocanů ve skupině 2 obsahovaly v závislosti na věku drůbeže 9,35 - 35,25 \% sojové moučky.

V letech 2002 a 2003 byly na krůtích jatkách odebrány vzorky porážených krocanů. Po zchlazení na $+4{ }^{\circ} \mathrm{C}$ v nich byly stanoveny následující ukazatele: vaznost masa, obsah vody v mase a celkového množství tuku. Zbylé části vzorků se zamrazily a po shromáždění do větších celků se v nich zjišt'oval obsah celkové bílkoviny, čisté svalové bílkoviny, kolagenu a 9 mastných kyselin (kyselina myristová, palmitová, stearová, palmitolejová, olejová, eikosanová, eruková, linolová, linolenová).

Vyhodnocení výsledků ukázalo, že nepřítomnost masokostní moučky v krmných směsích neměla vliv na ukazatele ovlivňující technologické vlastnosti masa (vaznost masa, obsah vody v mase, obsah celkové a čisté svalové bílkoviny, obsah kolagenu).

Výsledky práce však prokazují, že nahrazením masokostní moučky sójou dochází v prsní svalovině ke snížení obsahu celkových lipidů $(p<0,05)$ a ke změně složení mastných kyselin. Došlo ke zvýšení obsahu mastné kyseliny palmitové, stearové a eikosanové. U posledně jmenované je rozdíl významný $(p<0,05)$. U téže skupiny ptáků došlo ke snížení obsahu kyseliny olejové $(p<0,01)$. Změny v množství tuku a spektru mastných kyselin v krůtí svalovině mohou být významné z pohledu zdraví člověka (resp. kardiovaskulárních a nádorových onemocnění).

\section{Acknowledgement}

This study was supported by the grant No. MSM 6215712402 from the Ministry of Education, Youth and Sport of the Czech Republic.

\section{References}

AYERZA R, COATES W, LAURIA M 2002: Chia seed (Salvia hispanica L.) as an omega-3 fatty acid source for broilers: Influence on fatty acid composition, cholesterol and fat content of white and dark meats, growth performance, and sensory characteristics. Poult Sci 81: 826-837

BAGGIO SR, VICENTE E, BRAGAGNOLO N 2002: Cholesterol oxides, cholesterol, total lipid and fatty acid composition in turkey meat. J. Agric Food Chem 50: 5981-5986

BLAŽKOVÁ E, ZELENKA J, KOMPRDA T 2001: Vliv intenzity růstu na obsah mastných kyselin v krůtím mase. In: Sborník konference s mezinárodní účastí IV. Kábrtovy dietetické dny, VFU Brno, pp. 32-35

BRENDL J 1970: Vaznost masa. (In Czech, Meat-binding characteristics) 1. vyd. ČAZ - VÚPP, Praha, pp. 24-25

ČSN 576021 1999: Metody zkoušení výrobků z masa a sterilovaných pokrmů v konzervách - Stanovení obsahu vody (Referenční metoda). (In Czech, Reference method for establishing water cotent in meat products and sterilised tinned foods) Český normalizační institut, Praha, p. 8

DECKER EA, CANTOR AH 1992: Fatty acids in poultry and egg products. In: CHOW CK (Ed.): Fatty acids in foods and their health implications. Dekker, New York, pp.137-167

FERREIRA MM, MORGANO MA, QUEIROZ SC de, MANTOVANI DM 2000: Relationships of the minerals and fatty acid contents in processed turkey meat products. Food Chem 69: 259-265

ISO H, REXRODE KM, STAMPFER MJ, MANSON JE, COLDITZ GA, SPEIZER FE, HENNEKENS CH, WILLETT WC 2001: Intake of fish and omega-3 fatty acids and risk of stroke in women. JAMA 285: 304-312

IZÁK Š et al. 1978: Hygiena potravín III. 1. vyd. Príroda, Bratislava, 365 p.

KIRSTEIN D 2005: Purchasing guidelines for meat and bone meal. http://nationalby-products.com/files/ MWPoultry3-15-05.pdf, accessed on January 23, 2006

KOMPRDA T, ZELENKA J, JAROŠOVÁA, FIALOVÁ M, BLAŽKOVÁ E, FAJMONOVÁ E 2001: Cholesterol and fatty acid content in breast and thigh meat of turkeys growing with different intensity. Arch Geflugelkd 65: $258-264$

KOMPRDA T, ZELENKA J, BAKAJ P, KLADROBA D, BLAŽKOVÁ E, FAJMONOVÁ E 2003: Cholesterol and fatty acid content in meat of turkeys fed diets with sunflower, linseed or fish oil. Arch Geflugelkd 67: 65-75

KOMPRDA T, ZELENKA J, FAJMONOVÁ E, FIALOVÁ M, KLADROBA D 2005: Arachidonic acid and long- 
chain n-3 polyunsaturated fatty acid contents in meat of selected poultry and fish species in relation to dietary fat sources. J Agric Food Chem 53: 6804-6812

LORGERIL M DE, SALEN P, MARTIN JL, MAMELLE N, MONJAUD I, TOUBOUL P, DELAYE J 1996: Effect of a Mediterranean type of diet on the rate of cardiovascular complications in patients with coronary artery disease. Insights into the cardioprotective effect of certain nutriments. J Am Coll Cardiol 28: 1103-1108

LABUDA J 1973: Výživa a kŕmenie vysokoúžitkových zvierat v podmienkach vel'kochovov. (In Slovak, Feeding and nutrition of cattle in large-scale breeding conditions.) Príroda, Bratislava, pp. 46-75, 112-116, 332-340

LABUDA J 1975: Výživa a kŕmenie hospodářských zvierat. (In Slovak, Feeding nad nutrition of farmer animals) Príroda, Bratislava, 529 p.

NAM KT, LEE HA, MIN BS, KANG CW 1997: Influence of dietary supplementation with linseed and vitamin $\mathrm{E}$ on fatty acids, $\alpha$-tocopherol and lipid peroxidation in muscles of broiler chicks. Anim Feed Sci Technol 66 : $149-158$

NOVOVIČOVÁ J 1999: Pravděpodobnost a matematická statistika. (In Czech, Probability and mathematic statistics.) ČVUT, Praha, 157 p.

OKUYAMA H, KOBAYASHI T, WATANABE S 1997: Dietary fatty acids-the n-6/n-3 balance and chronic elderly diseases. Excess linoleic acid and relative n-3 deficiency syndrome seen in Japan. Prog Lipid Res 35: 409-457

RULE DC, BROUGHTON KS, SHELLITO SM, MAIORANO G 2002: Comparison of muscle fatty acid profiles and cholesterol concentrations of bison, beef cattle, elk, and chicken. J Anim Sci 80: 1202-1211

SILVA DA RG, DO PRADO IN, MATSUSHITA M, DE SOUZA NE 2002: Dietary effects on muscle fatty acid composition of finished heifers. Pesqui Agropecu Bras 37: 95-101

STEINHAUSER L 1995: Hygiena a technologie masa. LAST Brno, $664 \mathrm{p}$.

ZDRAVOTNÍ ÚSTAV SE SIDLEM V PARDUBICÍCH 2004: Tuky ve výživě a zdraví. (In Czech, Lipids in nutrition and health.) http://www.zupu.cz/printer.php?pid=178, accessed on January 16, 2006 